\title{
LAVOISIER'S THEORY OF THE EARTH
}

\section{By RHODA RAPPAPORT*}

IN the commonly understood meaning of the phrase, Antoine-Laurent Lavoisier did not write a 'theory of the earth'. That he intended to do so, however, is recorded in a passage probably written in 1766 . There he announced a research programme, already begun, that would yield

des connaissances exactes sur les anciennes limites de la mer, sur le lit qu'elle occupait, sur l'ancienne disposition des continents; en un mot un système, toujours guidé par des expériences et des observations sûres, des changements arrivés au globe. ${ }^{\mathrm{T}}$

Although his ideas were soon to change, he promised in 1774 to make public the results of his geological research, and in 1788 he again declared his intention to continue his studies in order to arrive at conclusions about 'l'état de la surface du globe à différentes époques'. " Had he been able to carry out these projects, Lavoisier's theory of the earthboth the early theory and his mature one-would have differed markedly from those being written by his contemporaries, since Lavoisier displayed little interest in such topics as the formation of the earth's 'primitive core' and the role of volcanoes and of the Deluge. Instead, from the beginning of his career in geology, Lavoisier selected and emphasized problems of sedimentation and stratigraphy that could shed light on the evolution of the earth's crust.

Lavoisier's youthful theory of the earth is of particular interest for its combination of traditional and novel elements and for the inadequacies that led him to abandon it. At the end of $\mathrm{I} 766$ he began to formulate a new theory, one based upon the principles later set forth in his famous memoir 'Observations générales sur les couches modernes horizontales qui ont été déposées par la mer et sur les conséquences qu'on peut tirer de leurs dispositions relativement à l'ancienneté du globe terrestre', completed by 1789 and published in 1793 . This memoir occupies an anomalous place in both the history of geology and the biography of its author. Written in a period when Lavoisier is commonly said to have abandoned the geological studies of his youth, the memoir appears to have no immediate biographical context; and its brilliance has led

* Department of History, Vassar College, Poughkeepsie, New York I2601, U.S.A.

An earlier version of this study was presented (in absentia) to a meeting of the Asociacion Argentina de Historia de la Ciencia, Córdoba, Argentina, 28 August 1970.

1'Extrait de deux mémoires sur le gypse', in Oeuvres de Lavoisier (6 vols., Paris, 1862-93), iii. ıog. The italics are mine. The second of the two memoirs on gypsum was read to the Académie des Sciences on 19 March 1766 , and this abstract was probably written after that date but before October 1766 , when Lavoisier modified his views on 'les anciennes limites de la mer'.

2 Opuscules physiques et chimiques (Paris, 1 774), in Oeuvres de Lavoisier, i. 441. I am indebted to Henry Guerlac for drawing my attention to this passage. See also R. Rappaport, 'Lavoisier's geologic activities, $1763-1792^{\prime}$, Isis, lviii $(1967), 3^{8} 3$, and note 33 .

THE BRITISH JOURNAL FOR THE HISTORY OF SCIENCE VOL. 6 NO. 23 (1973) 
historians to analyse it in isolation from its context in eighteenth-century geology. Within limits to be defined below, this study proposes to supply some of the biographical and geological background necessary to a fuller understanding of the memoir of I 789 . In addition, it will be shown that this memoir once formed part of Lavoisier's unwritten theory of the earth.

Placing Lavoisier's work in its historical context necessarily involves some examination of his relationship to his predecessors and contemporaries. At least, this can and must be done for his early work, in the period $1763-6$. His more mature ideas present different problems in that they probably originated in his own youthful studies, with minimal influence exerted by his teachers and other contemporaries.

Lavoisier was always reluctant to reveal the inspiration behind his ideas, but for his geological research he did once refer to the particular debt he owed to the writings of Buffon, the lectures of G. F. Rouelle, and conversations with J. E. Guettard.3 While it is possible to find parallels between Lavoisier's ideas and those of still other contemporaries, such parallels would not constitute proof of indebtedness, and Lavoisier's own admission therefore provides the most useful point of departure. However, there remains some difficulty in determining precisely what Lavoisier owed to each of his mentors. The conversations with Guettard cannot now be reconstructed, and one can only assume that the ideas in Guettard's writings are those to which Lavoisier was exposed. Rouelle's geological teachings receive brief and unsatisfactory treatment in the manuscripts of his chemistry lectures, and ideas which contemporaries attributed to Rouelle are sometimes lacking entirely from the manuscripts. The geological and cosmological views in Buffon's Histoire naturelle may well have inspired Lavoisier; but Buffon's text is also rich in casual suggestions, and historians cannot be certain that Lavoisier noticed some of these asides. The existence of such lacunae does not render all analysis meaningless, but some questions about Lavoisier's early career must remain unanswered.

For the period after about I770, Lavoisier's manuscripts yield little of geological interest, and this limits to some extent what the historian can do to trace the later development of his ideas. Nonetheless, two kinds of analysis are possible. The first is a comparison of Lavoisier's mature ideas with those of certain of his contemporaries; this method will be used very sparingly in this paper because mere similarity of ideas, in the absence of corroborative evidence, is inconclusive. For reasons that will appear below, it seems more instructive to treat Lavoisier's mature writings as an outgrowth of his own early work in geology. Indeed, it will be shown that his early notes can properly be used to supply the immediate background for ideas he was expressing twenty years later.

3 Oeuvres de Lavoisier, v. 226. Cf. H. Guerlac, 'A note on Lavoisier's scientific education', Isis, xlvii (1956), 2 1 $1-16$. 
The first phase: ${ }_{17} 6_{3}-6$

These three years of what might be called Lavoisier's geological apprenticeship were marked by intensive field-work, the development of observational skills, and increasing use of such techniques as chemical analysis and barometric measurement. In I $_{7} 63$ he had read Buffon, had attended or was attending Rouelle's lectures, and was beginning to take field trips in the company of Guettard. 4 Not surprisingly, then, this was the period in which Lavoisier expressed geological views close to those of his teachers. Furthermore, he was using some of the special vocabulary developed by Rouelle and Guettard, and he occasionally referred to one or another of his teachers in a manner which suggests that he was working within and trying to verify portions of their geological theories.

Among the ideas shared by Guettard, Rouelle, and Buffon-and other geologists of the period-was the belief that the earth's crust consists of two major groups of formations: the unfossiliferous, largely granitic masses which Rouelle called the terre ancienne, and the more recent, fossiliferous, sedimentary terre nouvelle. (Volcanic and alluvial terrains were considered to be relatively less important in the overall history of the earth.) Sedimentary formations had been deposited during an era when the sea covered all or most of the present continents, except perhaps for the peaks of the highest mountain ranges; this era had ended when the waters had somehow retreated and exposed the present land masses. Such occurrences as the appearance from time to time of new islands did not impair the general picture adopted by Lavoisier's teachers, and, with the possible exception of Buffon, they assumed that the sea had only once covered the land. In short, the entire terre nouvelle was the product of continuous deposition (perhaps interrupted occasionally in some localities) in a deep and stationary sea.5

Lavoisier's teachers all discussed the dynamics of sedimentation and distinguished between what their pupil later called pelagic and littoral beds. ${ }^{6}$ But they did not explain clearly the relationship of this subject to their general theory of the earth, and so they left wholly or partially unanswered the question: if the terre nouvelle was laid down on the ocean floor, why then do some of its strata appear to be littoral in origin? The question did not arise in connexion with present shorelines, and Buffon was able to describe at length their gradual elevation or

4 Details of his activities during this period are in Rappaport, op. cit. (2).

5 Buffon, 'Theorie de la terre', in Oeuvres completes de Buffon, ed. J.-L. de Lanessan (14 vols., Paris, $\mathbf{1}_{88}-5$ ), i. $34^{-66}$, and 'Cours de chymie de M. Rouelle, rédigé par M. Diderot et éclairci par plusieurs notes', Bibliothèque Municipale de Bordeaux, MSS. 564-5, pp. 567-82. Guettard never emphasized a general theory of the earth but at least once he expressed views close to those of Buffon and Rouelle and claimed to have held them for some years (Muséum d'Histoire Naturelle, Paris, MS. 2193 , ff. 18-20).

${ }^{6}$ The term 'pelagic' had a broader meaning in the eighteenth century than at present, signifying anything to do with the open seas, at any depth; and it will be used in that sense throughout this study. See also note 34 . 
degradation as the sea engages in a perpetual shift from East to West around the globe. But littoral deposits far from modern seas posed a problem of interpretation that even the ingenious Buffon found difficult of solution. In fact, he offered two mutually exclusive explanations. On one occasion Buffon suggested that alternating littoral and pelagic formations could be attributed to the fact that the seas 'ont . . . couvert et peuvent encore couvrir successivement toutes les parties des continents terrestres'.7 More often, however, his analysis resembles the theory put forward earlier by Benoît de Maillet in Telliamed ( $174^{8}$ ). Believing that the ocean floor can be agitated by strong currents, Buffon concluded that most of the earth's mountains had been built up by the combined action of sedimentation and erosion taking place on the ocean floor; hence, the present land masses consist of sedimentary formations which are all deepwater in origin. 8

Unlike Buffon, Rouelle believed that disturbances extend to a depth of only ten or twelve feet below the surface of the sea; logically, therefore, littoral formations could not have originated in deep water. The evidence that Rouelle attempted to explain this problem is slender and indirect, and it seems he may have believed that littoral formations (but not single beds) mark the boundaries of former sea basins. 9 If this statement accurately represents his ideas, then Rouelle clearly had a more sophisticated view than either Guettard or Buffon of a once complex distribution of sea basins and land masses. But neither Rouelle nor his contemporaries offered a solution for the problem of single, apparently 'anomalous', littoral beds that 'interrupt' formations otherwise pelagic in origin.

Each of Lavoisier's teachers added distinctive touches to the broad theory which was shared by all, and the most significant of these additions for the present study are Guettard's concept of the geological bande and Rouelle's definition of the tractus. Bandes were divisions of the earth's superficial crust into regions characterized by the predominance of certain rocks and minerals. For France, Guettard outlined a Bande sableuse with its centre near Paris and consisting mainly of sandstones and limestones; the Bande marneuse circumscribed the sableuse and was in its turn surrounded by the Bande schisteuse ou métallique. The scheme was a lithological one, taking no account of the relative age of formations or of palaeontology. ${ }^{\text {io }}$

7 Buffon, op. cit. (5), i. $5^{6}$.

8 Ibid., i. 34-66, 104 ff. Cf. Guettard, 'Mémoire sur les poudingues. Seconde partie, Mémoires de l'Académie Royale des Sciences, 1753 (1 757), pp. 18 I-2. Gf. Benoît de Maillet, Telliamed, trans. and ed. Albert V. Carozzi (Urbana, Illinois, I968), especially pp. 65-72, and Carozzi's comments on Buffon on p. 4.

9 Rouelle cited by Lavoisier; see below, p. 252.

ro Guettard, 'Mémoire et carte minéralogique sur la nature \& la situation des terreins qui traversent la France \& l'Angleterre', $M \dot{k} m$. Acad. $R$. Sci. $I 746$ (1 751), pp. 363-92. See also R. Rappaport, 'The Geological Atlas of Guettard, Lavoisier, and Monnet: conflicting views of the nature of geology', in C. J. Schneer (ed.). Toward a history of geology (Cambridge, Mass., 1969), pp. 272-87. 
Rouelle's tractus was a division of sedimentary strata on the basis of fossil populations. France was marked off into a number of 'cantons',

déterminés par le coquillage qui s'y trouve le plus abondamment, et il [Rouelle] a appellé centre de ce canton ou de ce tractus . . . le lieu où ce coquillage se trouve en plus grande quantité. De là jusqu'à l'extrémité de ce canton ce coquillage vient de plus en plus rare; mais aussi à mesure qu'on s'éloigne de ce centre on trouve de nouveaux coquillages dont le nombre augmente continuellement; et on parvient enfin ... [au] centre d'un nouveau Tractus. ${ }^{\text {II }}$

Rouelle's system was based on the idea, not uncommon at the time, that the ocean floor of the past resembles that of the present and that, therefore, fossil populations in the strata, like their living analogues, are grouped together as colonies in which particular species predominate. There is no evidence that he assigned different species to different periods of geological time, and in his neglect of time his approach was not unlike that of Guettard.

During the years $176_{3}-6$ Lavoisier adopted significant elements of the theory of the earth expounded by his teachers, while, at the same time, he modified and eventually abandoned those concepts attached to the terms bande and tractus. The latter process of modification appears most clearly in Lavoisier's reference, in 1765 , to 'cette partie basse du globe qui a été couverte par les eaux de la mer, et que quelques naturalistes ont appelée la bande ou le tractus calcaire'. ${ }^{2}$ In a single sentence Lavoisier has equated three quite different ideas. 'Cette partie basse' was the phrase he commonly used for all the sedimentary formations that comprise the terre nouvelle, while neither bande nor tractus had ever possessed so broad a meaning. In fact, Lavoisier has so confused these special terms that the only clear idea to emerge from his statement is a distinction between sedimentary formations and older masses. Similarly, he referred to ore-bearing strata as belonging to Guettard's Bande schisteuse and Rouelle's terre ancienne; both phrases are here used correctly, but Guettard's lithological concept and Rouelle's stratigraphic one are not equivalent.13 So, while employing the vocabulary of two of his teachers, Lavoisier actually dispensed with some of the variations and refinements in their ideas and retained the simpler stratigraphic scheme which they shared with Buffon.

The key idea that Lavoisier adopted without modification was his teachers' assumption that there had been only one era of deposition in stationary seas. Hence, when in 1766 he announced his intention of preparing a theory of the earth, he referred to 'le lit' formerly occupied

"Rouelle, op. cit. (5), p. 574. On occasion Rouelle also used tractus lithologically, for example in tractus calcaire (ibid., p. 572).

12 Oeuvres de Lavoisier, iii. 126.

13 Ibid., iii. 135. 
by the sea. Elsewhere he described sedimentary formations as occupying that part of the earth's crust 'où la mer paraît avoir séjourné pendant des siècles'. 4 At the same time he came to doubt that all sediments could have originated on the ocean floor. In an early (undated) note no such doubt is apparent, and he produced diagrams which illustrate Buffon's theory of mountain building. ${ }^{15}$ In 1765 , however, he explicitly criticized Buffon's theory on the grounds that littoral and pelagic formations should not be explained by the same mechanism of deposition. ${ }^{16}$ This noteworthy change in Lavoisier's thinking may well have been the result of Rouelle's teaching, as is implied in a note written in that same year, i 765 . Here Lavoisier remarks upon strata of coarse limestone and sandstone superimposed upon much finer sandstone; the position of these beds suggested deposition under the same conditions and during a single epoch, but their lithology suggested respectively littoral and pelagic origins. More careful observation, he goes on to say, convinced him that the fine-grained sandstone did not actually pass under the other strata but seemed to be 'appliqué Contre [eux]'. He thus interpreted the littoral deposits as revealing the former limits of the sea basin, and he concluded triumphantly that these observations served as 'confirmation aux idees de $\mathrm{m}^{\mathrm{r}}$ rouelle et aux miennes'. ${ }^{17}$ This brief episode not only illustrates Lavoisier's departure from the ideas of Buffon, but it also explains the way in which he was using pelagic-littoral distinctions in his research programme to chart precisely 'les anciennes limites de la mer'.

By i 765 Lavoisier's theory of the earth closely resembled Rouelle's in its major tenets: a single era of deposition, a complex distribution of sea basins and land masses, and important distinctions drawn between pelagic and littoral formations. It has already been noted that a theory of this kind left unexplained those littoral beds which seem to 'interrupt' pelagic formations. This problem did not go unnoticed by Lavoisier who, in field notes of June 1765 , remarked upon a bed of sandstone which seemed to be 'out of place', or, as he put it, 'vraisemblablement accidentel car il est enclavé dans les bancs Calcaires'. By invoking the then common device of the geological 'accident' - which might be defined as a negligible break in the otherwise predictable course of nature-Lavoisier was for the moment able to ignore an anomaly. At this stage in his thinking, Lavoisier could interpret certain littoral formations as the remnants of

14 Ibid., iii. 137

15 Ibid., v. $12-13$.

${ }^{16}$ Lavoisier Papers, Académie des Sciences, dossier 420 (notes dated I 765, on the route from Paris to Senlis).

${ }_{17}$ Lavoisier Papers (16), dossier 423 (25 March 1764). To judge from other notes in this dossier, the date should actually read I 765 . It is possible, too, that Lavoisier had read the work of one of Buffon's severest critics: R. E. Raspe, Specimen historiae naturalis globi terraquei (Amsterdam, I 763). This volume was in Lavoisier's library. Of the several catalogues of the library, I have consulted the 'Catalogue des livres de la bibliotheque de Madame la Comtesse de Rumford' (2 vols.), in the Lavoisier papers, Cornell University Library; see especially i. 62-80. 
ancient shorelines, but the occasional littoral bed was merely an 'accident' that need not be taken into account in a general theory of the earth. ${ }^{18}$

Pelagic-littoral problems were to increase in importance for Lavoisier towards the end of 1766 , while before that date his attention was as often directed towards two other activities fundamental to his theories: his barometric measurements and the construction of what he called coupes générales, or general sections. Lavoisier used the barometer to measure the thickness and altitude of strata, his aim being to identify precisely and then trace the lateral extent of each bed. At a time when the stratigraphic significance of fossils was not recognized, identifying similar strata in two outcrops was a matter of lithology and position; and Lavoisier was using the barometer for a more accurate determination of position. Although this technique was probably learned from Rouelle, the potential usefulness of such measurements was not immediately obvious to Lavoisier; he was not yet using a barometer habitually in 1764 , customarily carried one or two barometers by 1766 , and in 1767 described himself as climbing mountains 'le barometre a [sic] la main'.19 In his desire to study the continuity of sedimentary formations Lavoisier was doing, systematically and with precision, what two of his teachers had advocated but scarcely practised. There is no evidence that Rouelle used the barometer with any regularity, although demonstrating the continuity of sedimentary strata was one of his principal concerns. The latter was of even greater interest to Guettard, since he continually sought to refine his system of bandes; but barometric measurement was used by Guettard only for meteorological purposes. By contrast, Lavoisier came to believe that precise measurement would provide a firm foundation for his theory of the earth. The research programme he described as already begun in 1766 was, in fact, a series of such measurements.

By the early months of 1766 Lavoisier was using his barometric data to construct general sections. These composite, idealized sections were put together after examination of the various outcrops visible in any given locality. 20 While each section represented the general order of strata in one locality, the construction of such sections for the several regions of France would eventually yield a broader picture of geological change. Here too Lavoisier's ideas show a certain resemblance to those of his teachers. Both Guettard and Buffon had commented earlier on a general order discernible in sedimentary strata, Guettard then using as his example the environs of Paris and Buffon describing what he considered

${ }^{18}$ Lavoisier Papers ( 16 ), dossier 420 (3 June 1765). This kind of explanation was (and is) not unusual; cf. Guettard (op. cit. [10]), who admits the existence of local exceptions to his system of bandes, but says they do not invalidate the scheme he is proposing.

19 Rappaport, op. cit. (2), 378-9, and op. cit. (10), 281 . Buffon noted briefly that the barometer can be used to measure accurately the height of mountains; see Oeuvres completes de Buffon, i. 136 .

zo Oeuvres de Lavoisier, v. 75. See also Lavoisier Papers (16), dossiers 415, 419, and Rappaport, op. cit. (ro), 282 . 
to be the universal order of all strata composed primarily of vitrifiable materials. Closer reading, however, reveals that Guettard was simply adopting this device as a way of making rapid generalizations, while Buffon, typically, was seeking to formulate global laws. Lavoisier was doing neither but was trying to show that orders of deposition can be established for particular regions. In addition, Lavoisier, far more than his teachers, stressed the geological importance of the general section; indeed, it was Lavoisier who insisted that general sections be included on the geological maps that he was preparing in collaboration with Guettard, while Guettard did not fully realize why the matter should be so significant. ${ }^{21}$

\section{Maturity: 1766 and 1789}

By the autumn of 1766 Lavoisier was equipped with a geological theory that he was testing in the field, and his skills had developed to such an extent that he was doing independent and original work in geological cartography. But, despite some modifications in the ideas he had inherited, the general framework he was using remained essentially that of his teachers. This state of affairs continued until October 1766 , when he announced: 'Je Commence de Ce moment a Considerer toutes ces choses Sous un aspect tres different'. ${ }^{22}$ The occasion of this remark was a geological excursion to Brie, and 'ces choses' is a reference to pelagiclittoral problems. His observations, he goes on to say, seemed suddenly to require profound changes in his theory of the earth. These changes were to affect all his subsequent thinking in geology and were ultimately to supply the basis for his memoir of 1789 .

While in Brie in 1766 , Lavoisier once again noticed a series of beds alternately littoral and pelagic, but this time he could not resort to the device of the geological 'accident'. As he put it, to find limestone resting upon sandstone now struck him as a common rather than a rare phenomenon and therefore one that required attention. He thus began to consider the possibility that 'les pierres Calcaires reposent non pas Sur la terre primitive ...., Sur l'ancienne terre, mais Sur des matierres que la mer a elle meme deposée lorsquelle [sic] gagnoit Sur les terres'. The latter 'matierres', littoral deposits, entered deeper water as the seas advanced. With time and tranquillity, pelagic beds were deposited horizontally atop the littoral until the seas began to subside, restoring those conditions under which littoral beds had earlier been formed. Thus, he concluded,

"See Oeuvres completes de Buffon, i. especially 229-30, and Guettard, 'Description minéralogique des environs de Paris', Mlm. Acad. R. Sci. 1756 (1762), pp. 225-7. Disagreement between Guettard and Lavoisier on the subject of map-making is discussed in Rappaport, op. cit. (I0), especially $27^{8-9}$.

${ }_{22}$ Lavoisier Papers ( 16 ), dossier 421 : 'Observations mineralogiques faittes en $8^{\text {bre }}$ i 766 dans [une] partie du vallois du Soissonnois de la champagne et de la Brie', ff. Iv-2r. 
we can discern 'trois formations bien differentes pour la datte dans les bancs que nous habitons', and by going deeper within the earth's crust we might find three more. 23

Lavoisier had clearly arrived at a rather different conception of the evolution of the sedimentary crust than was possessed by his teachers. Indeed, by implication at least, he was also raising questions about the possibly sedimentary origins of portions of the terre ancienne. Moving decisively away from the idea of a single era of deposition in stationary seas, he postulated a succession of ages characterized by a cyclically advancing and subsiding ocean.

How did Lavoisier arrive at these revolutionary ideas? The possible influence of Buffon must be discounted. Lavoisier may well have noticed Buffon's brief comments on the present land masses having been successively covered and then exposed by the sea; but Lavoisier had read the first volumes of the Histoire naturelle by 1763 , and yet had paid no attention to an idea that he was to find so fruitful three years later. Lavoisier's own explanation, that his observations in Brie provided the needed inspiration, is probably as close to a satisfactory analysis as we can come. It is significant that he remarked not on the novelty of his observations but on the fact that such phenomena were more common than he had realized. One might well ask, when does a particular phenomenon cease to be rare and begin to seem common? To attempt an answer would require an excursion into philosophy and psychology for which evidence, in Lavoisier's case, is lacking.

It is at this critical stage in Lavoisier's development that the documents become sparse and unsatisfactory. As he stated in the journal of his voyage to Brie, his new theory would benefit from additional fieldwork, and for the years $1767-71$ there are records of geological trips to Alsace and Lorraine, Champagne, Flanders, and Picardy. However, his well-known journey with Guettard to Alsace and Lorraine in 1767 did little to support his theory because he examined areas so disturbed geologically that he was unable to establish the general order of the strata. ${ }^{24}$ Other terrains explored during this period could have provided useful data, but Lavoisier's travel journals give no indication of the ways in which his theory was being developed or confirmed. The journals, in fact, contain field observations similar to those Lavoisier had been making for years, as well as his usual barometric measurements. After I 77 I there is a dwindling record of field-work consisting of voyages to Brittany in 1778 and to Orléanais, Burgundy, and Normandy in 1787 and 1788 . Like certain of the earlier voyages, these were not primarily geological

23 Ibid., ff. 2r, 2v, 3 r.

24 This is evident from an examination of the maps based on this voyage; the relevant map numbers and titles are given in D. I. Duveen, Supplement to a bibliography of the works of Antoine Laurent Lavoisier $1743^{-1} 794$ (London, 1965), pp. 131-2. 
in purpose, and Lavoisier's notes, with the exception of some observations at the coast near Cherbourg, are singularly unrevealing. ${ }^{25}$

These lacunae are less serious than one might suppose. Examination of Lavoisier's notes of the I 760 s shows that they are sufficiently detailed and precise to have been of value to him twenty years later. In fact, his few examples of field observations in the memoir of 1789 are virtually all references to his earliest yoyages: thus, repeated allusions to coastal deposits in Normandy do not stem from his visit there in 1788-his memoir was then already drafted and the results of that voyage were placed in a footnote-but rather to knowledge acquired during a field trip in 1765 . Furthermore, Lavoisier's mature ideas were based only in part on field-work, while elements were also drawn from laboratory analysis; for example, when in 1789 Lavoisier remarked on the relative purity of clayey or calcareous materials in particular sedimentary formations, some of his information came from the analysis of specimens in his own mineralogical collection and that of the Académie des Sciences. 26 After 1 766, therefore, it was entirely possible for Lavoisier to work out the details of his theory without additional observations in the field. His real need was instead to study and reinterpret the data he already possessed.

Lavoisier's memoir of 1789 can now be examined as his mature statement of observations and ideas dating from his youth. The burden of the memoir is to demonstrate that sedimentary formations are the work of an alternately advancing and subsiding ocean. To this end he presented a detailed theoretical analysis of the deposition of pelagic and littoral strata illustrated by a series of diagrams showing the process occurring under ideal conditions. Assuming, he continued,

que la mer ait eu un mouvement d'oscillation très lent, une espèce de flux et de reflux, dont le mouvement se soit exécuté dans une période de plusieurs centaines de milliers d'années, et qui se soit répété déjà un certain nombre de fois, il doit en résulter qu'en faisant une coupe de bancs horizontaux ... cette coupe doit présenter une alternative de bancs littoraux et de bancs pélagiens.

And one should then be able to judge from the number of beds 'le nombre d'excursions que la mer a faites'. To show that observations in the field do support these contentions, Lavoisier constructed a series of vertical sections for areas near Villers-Cotterets, Meudon, and St Gobain. ${ }^{27}$

25 The journals are at the Académie des Sciences and at Cornell University Library. For a discussion of the period after $177^{\circ}$ see Rappaport, op. cit. (2), $380-4$.

${ }_{26}$ Oeuvres de Lavoisier, v. 187,203 . Cf. a minute of a letter from Lavoisier to the Académie (undated but written after Guettard's death on 6 January 1 786), Lavoisier Papers, Cornell University Library, MS. 29. In this letter Lavoisier emphasizes that specimens he wants to analyse must be clearly identified as to place of origin.

${ }_{37}$ Oeuvres de Lavoisier, v. 198 and Plates. He also noted that the superior beds can be destroyed by a subsiding ocean and that the number of beds therefore may be fewer than the number of 'excursions' of the sea. 
It is clear that the key idea in this memoir had been fully formulated by Lavoisier in 1766 , and the vertical sections, too, represent regions that Lavoisier knew well and had mapped in detail by $1766 .{ }^{28}$ Furthermore, elements in his theoretical analysis of the configuration of pelagic and littoral beds had long since been worked out, and it is a simple matter to select passages from the memoir of 1789 and to find clear parallels in notes dating from 1765 and 1766 (see Appendix). Preliminary versions of the diagrams used in 1789 still exist, and it is possible that these too were prepared as early as $177^{\circ}$; however, the dating of these sketches remains problematical.29 In short, there is no doubt that Lavoisier possessed significant parts of his analysis of pelagic and littoral beds quite early in his career and that late in 1766 he developed the theory which was ultimately incorporated into his published memoir.

A second point of major importance to Lavoisier, as the full title of his memoir reveals, was his desire to provide evidence for the antiquity of the earth. In a preliminary précis of the memoir, he had in fact remarked that 'tout atteste que le globbe que nous habitons est dune anciennete pour ainsy dire incalculable'.30 Modifying this statement for publication, he simply observed that the slowness of marine oscillations could be measured by 'plusieurs centaines de milliers d'années'. That he had in mind some further extrapolation is implied in his comment that the expression terre ancienne is not especially precise, and that these so-called primitive masses are probably 'un composé de bancs littoraux beaucoup plus anciennement formés'. This lengthy evolution of the earth's crust he planned to investigate in a series of memoirs that would treat, among other topics, the condition of the crust at various stages in the past and the development of life on its surface. $3^{\mathrm{I}}$

As noted earlier, Lavoisier's suspicion that part of the terre ancienne might be sedimentary in origin dated from i 766 . The rest of his evolutionary analysis and his views on geological time, however, have no clear precedent in his youthful notes, although the latter do contain some suggestive comments. Such, for example, is his statement in 1766 , quoted above, that the alternating formations observed in Brie were 'bien differentes pour la datte . .', and that further examination might show such strata recurring at greater depths beneath the earth's surface. Both in the early notes and in the mature memoir Lavoisier often referred loosely to periods of 'centuries'; while in 1789 it is clear that he had a

${ }^{28}$ Ibid., v. 48-52, 72-83. The corresponding maps are dated 1766 and numbered 26 and $40^{\mathrm{bta}}$, the former in the Atlas et description mineralogiques de la France (Paris, 1780 ), the latter in the rare second edition of the Atlas and reproduced in Rappaport, op. cit. (10), 280.

${ }^{29}$ Muséum d'Histoire Naturelle, Paris, MS. 237, folder 6. An early date is suggested by the fact that the sketches are accompanied by a separate note dated 1770 and are in a folder labelled by Lavoisier: 'Histoire naturelle memoire/generale/Tractus Calcaire. (Coupes géologiques.)'. The term tractus is characteristic of his youthful notes. Evidence for a later date includes the use of the word 'geologie', which was not widespread in France before about 1780 .

$3^{30}$ Lavoisier Papers (16), dossier 335B, f. 2 v.

${ }^{31}$ Oeuvres de Lavoisier, v. 201-4. 
longer time scale in mind, there is no way of judging whether the same can be said about his thinking in the 1760 s. If his ideas on the time scale did undergo some development between 1766 and 1789 , there is no evidence permitting us to explain when and why this happened, although a few conjectures can be hazarded. Lavoisier's library is known to have contained at least two works which emphasize a great extension of the time scale: Buffon's Les époques de la nature ( 1778 ) and J. T. Needham's Théorie de la terre (1769). ${ }^{2}$ In fact, bold statements about the age of the earth were becoming increasingly common, and it would have been difficult for Lavoisier to have avoided exposure to such ideas. In any case, his theory certainly required long periods of time to accomplish major and repeated displacements of land and sea, and Lavoisier, unlike Needham and Guettard, was not a man to resist the implications of his own ideas. What made Lavoisier's memoir unusual for its day was not the fact that he adopted a long time scale, but rather his use of marine oscillations as the basic evidence in support of the new geochronology.

Although Lavoisier's reliance upon ideas formulated or outlined in 1766 was considerable, the memoir of 1789 does possess some features which are not to be found in his early work and whose origin is not readily identifiable. Among these, for example, are his brief comments on the gradual development of life on earth-this idea was not uncommon in the eighteenth century-and his remark on the equilibrium of coastlines that would prevail were it not for gradual shifts in the position of the sea basin.33 Noteworthy too is the memoir's increased sophistication and richness in analysis (see Appendix). There are, furthermore, stylistic changes which cannot be dismissed on the grounds that a polished memoir would naturally differ from a series of field notes. Not only have bande and tractus vanished, but there is the adoption and consistent use of the terms 'pelagic' and 'littoral', chosen to avoid circuitous phrases.34

32 See J. T. Needham, Recherches physiques $\&$ métaphysiques sur la nature $\mathbb{E}$ la religion, \& une nouvelle theorie de la terre, in Lazzaro Spallanzani, Nouvelles recherches sur les decouvertes microscopiques, et la génération des corps organises (2 vols. in I, London and Paris, 1769), ii. especially 82, 102-3, where Needham uses sedimentation rates as evidence for an extended time scale. Lavoisier's copy of this work is at Cornell University and, although used in appearance, contains no marginalia.

33 The latter point, often emphasized by historians of geology, has here been subordinated to those ideas which Lavoisier himself considered most important and treated at length. Lavoisier emphatically attributed to the mathematician Gaspard Monge his ideas on the development of life on earth; see Oeurres de Lavoisier, v. 202. Monge is not known to have had any competence in geology, but some evidence for his interest in natural history and his participation in conversations in Lavoisier's laboratory can be found in Paul V. Aubry, Monge: le savant ami de Napoleon Bonaparte, I746-1818 (Paris, 1954), pp. 30, 39, and René Taton, L'oeuvre scientifique de Monge (Paris, 1951), p. 324 .

34 Lavoisier Papers (16), dossier 335 C, f. 4v, and Oeuvres de Lavoisier, v. 189. These terms occur here for the first time in Lavoisier's writings. In the published memoir he claimed to be following Rouelle's usage, but this is not borne out by the Rouelle manuscripts. Buffon is the only one of Lavoisier's teachers known to have used these terms and then in only one passage: Oeuvres complites de Buffon, i. 128. But the terms are Latinisms that Lavoisier could have found in other works, such as R. E. Raspe, An account of some German volcanos, and their productions (London, I 776), pp. 15, i 7. Raspe's book was in Lavoisier's library. 
If the words are of minor importance when compared with the ideas, this new vocabulary remains a significant symbol of the assurance with which Lavoisier expressed himself in 1789 , and their use gives his memoir an air of professional competence lacking in the earlier notes.

Having laid the foundations for a theory of the earth, Lavoisier was able to complete only one more geological memoir, his brief 'Mémoire sur la hauteur des montagnes des environs de Paris', presented to the Académie des Sciences in 1792 and published posthumously. Using as examples barometric measurements dating from I77I, he advocated the systematic application of this technique as the basis for investigating the geological history of France. These had been his aims in the period $1766-70$ when he was most active in the preparation of the geological atlas of France, and despite the fact that much of his early data would have to be discarded-he had been unable to correct for variations in his instruments-he announced his intention to resume these observations. 35 While his data were drawn from France, it is evident here, as in the memoir of 1789 , that Lavoisier meant to arrive at more universal conclusions about the structure of the earth's crust. In view of the solidity and brilliance of Lavoisier's achievements, historians can only regret that he did not live to complete this and other projects.

\section{APPENDIX}

The passages in the left column all date from 1765 and 1766 and are drawn from the Lavoisier Papers (cited in note 16 ), dossiers $4^{1} 7$ and 421 . Those in the right column are taken from the memoir of 1789 , printed in Oeuvres de Lavoisier (cited in note I), v. 191, 192, 194-5.

1. Les Cotes de dieppe Sont toutes garnies de Galets et voici ce quon observe; les plus gros et les plus arondis, ceux qui Sont dans le bas ressemblent presques a du gravier de Rivierre enfin encore plus bas dans lendroit qui nest decouvert que par les basses marées tout est Sable...

La mer ote donc aux cailloux leurs angles, les parties plus legeres detachees des Cailloux demeurent quelques instants flottante dans les eaux ce qui les entraine peu a peu dans la partie plus basse de Sorte que peu a peu a mesure quon avanceroit et qu'on S'eloigneroit de la Cote, on devroit trouver un Sable plus fin, ce qui est a examiner.
Les matières les plus grossières, telles que les galets, doivent occuper les parties le plus élevées, et former la limite de la haute mer. Plus bas doivent se ranger les sables grossiers qui ne sont eux-mêmes que des galets plus atténués; au-dessous, dans les parties où la mer est moins tumultueuse et les mouvements moins violents, doivent se déposer les sables fins; enfin, les matières les plus légères, les plus divisées ... doivent demeurer longtemps suspendues; elles ne doivent se déposer qu'à une distance assez grande de la côte, et à une profondeur telle que le mouvement de la mer soit presque nul.

33 Oeuvres de Lavoisier, v. 206, 213. 
II. les bancs formes a la Cote doivent S'abaisser de niveau a mesure quils approchent de la mer . . . les autres [i.e., pelagic beds] peuvent bien prendre a la verité une petite inclinaison lorsqu'ils Commencent a approcher de la Cote, mais quen tirant vers la plaine mer ils ont du remplir les creux et retablir le niveau.

III. [As the seas advanced and littoral deposits entered deep, tranquil water,] alors les Coquilliage[s] ont Commencé a pouvoir $\mathrm{y}$ vivre, les premiers qui y on[t] vecu ne Se trouvant pas encore fort eloignés de la Cote le Sable ou la glaise Sur les quels ils etoient poses a du recevoir asses d'agitation pour Se meler avec eux dela il a du arriver que les premiers bancs etoient de pierres Calcaires Sableuses.
Tous les bancs... qui se sont formés ainsi à la côte sont ceux que j'ai nommés bancs littoraux; enfin, on voit ... le commencement des bancs calcaires . . . formés en pleine mer des bancs que j'ai nommés pélagiens qui se continuent en s'approchant de plus en plus de la ligne horizontale ...

.. c'est alors que les animaux de la mer, ceux mêmes qui sont revêtus d'enveloppes fragiles et qui craignent le mouvement, ont commencé à s'y établir... Mais les animaux . . ont dû être incommodés quelquefois par les très grands mouvements de la mer, et . . . aussi des portions de sable fin ont pu demeurer assez longtemps suspendues dans l'eau, pour parvenir jusqu'à eux: les premières coquilles doivent donc encore aujourd'hui se trouver mêlées d'une portion de sable de même espèce que celui sur lequel elles reposent ... 